\title{
IAMJ
}

INTERNATIONAL

AYURVEDIC

MEDICAL JOURNAL

\section{CONCEPT OF TEXT NECK SYNDROME AND ITS MANAGEMENT THROUGH AYURVEDA}

\section{Md Tanzil Ansari ${ }^{1}$, Sukumar Ghosh ${ }^{2}$}

${ }^{1}$ P.G. Scholar, Department of Kayachikitsa, Institute of Post Graduate Ayurvedic Education and Research at Shyamadas Vaidya Shastra Pith, Kolkata, West Bengal, India

${ }^{2}$ Professor and HOD, Department of Kayachikitsa, Institute of Post Graduate Ayurvedic Education and Research at Shyamadas Vaidya Shastra Pith, Kolkata, West Bengal, India

Corresponding Author: tanzilansari23@gmail.com

\section{https://doi.org/10.46607/iamj2009022021}

(Published online: February 2021)

Open Access

(C) International Ayurvedic Medical Journal, India 2021

Article Received: 29/01/2021 - Peer Reviewed: 08/02/2021 - Accepted for Publication: 09/02/2021

\section{D) Check for updates}

\section{ABSTRACT}

Text neck syndrome is an emerging disease of today's world. The term 'text neck' is used to describe a repetitive stress injury or an overuse syndrome due to forward head flexion and bent down looking at handheld devices like mobile phone, tablet or other wireless electronic devices for prolonged period of time. Our young generation is at high risk of developing this disease because they spend their most of the times by hunching over the mobile phones. It is manifested by neck pain, neck stiffness, reduced mobility of neck and headache. If it is left untreated then it may lead to flattening of the spinal curve, onset of early arthritis, spinal misalignment, disc compression, disc herniation, nerve damage and muscle damage etc. It can be correlated with Manyastambha due to similarity in their symptoms. Manyastambha is characterized by neck pain, neck stiffness and restricted movements of neck. One should follow proper preventive measures to avoid Text neck syndrome, as we know 'Prevention is better than cure'. In this article Ayurvedic management of this disease has been discussed in detail. It includes Nidana parivarjana, Abhyanga, Ruksha Swedana, Nasya Karma, Greeva basti and Shamana aushadhis etc. along with these some Yoga-asanas have also been mentioned that are beneficial to combat this disease. 
Keywords: Ayurveda, Mobile phone, Text neck syndrome, Manyastambha.

\section{INTRODUCTION}

In this modern world, mobile phone has become the basic need of human population. Nowadays people of all the ages and all the sections use mobile phone, mostly our young generation. The number of smartphone users in India was estimated to reach over 760 million in 2021. On the other hand, number of smartphone users worldwide exceed to 3.8 billion (48.53\% of world's population) in $2021 .{ }^{1}$ Nowadays texting has become the common way of communication. Most of the people spend their times by texting, watching videos and doing other works in mobile phones. Excessive use of mobile phone produces ill effects to our health. This mostly affects our neck and produces Text neck syndrome which is an emerging disease of today's world. The term 'text neck' is used to describe the neck pain and damage sustained from looking down at mobile phone, tablet or other wireless electronic devices too frequently and for too long. ${ }^{2}$

Text neck syndrome can be correlated with Manyastambha due to similarity in symptoms like pain and stiffness in the neck. Its lines of treatment are $\mathrm{Ni}$ dana parivarjana (avoidance of etiological factors), Shodhana chikitsa (Purification therapy) and Shamana chikitsa (Palliative therapy). Along with these Yogaasanas also play important role for the management of this disease.

\section{Aim and Objectives}

1. To discuss about Text neck syndrome along with its Ayurvedic correlation.
2. To discuss about the Ayurvedic management of Text neck syndrome.

\section{Materials and Methods}

The present study is a Review article. So, different Ayurvedic texts, published research papers and available materials on internet have been reviewed for this article.

Concept of Text neck syndrome and its Ayurvedic correlation:

The new medical term 'text neck' was coined by a US Chiropractor Dr. Dean L. Fishman. It is also known as 'tech neck' or 'turtle neck posture' or 'anterior head posture'. ${ }^{3}$ The term 'text neck' is used to describe a repetitive stress injury or an overuse syndrome due to forward head flexion and bent down looking at handheld devices like mobile phone, tablet or other wireless electronic devices for prolonged period of time. $^{2}$

$75 \%$ of the world's population spends hours daily hunched over their handheld devices with their heads flexed forward, they are all in constant danger and at risk of developing Text neck syndrome. Frequent and prolonged forward head flexion leads to changes in the cervical spine, curve, supporting ligaments, tendons and musculature as well as the bony segments, commonly causing postural change. ${ }^{4}$

When a person flexes his head forward at varying degrees then it affects his spine directly. ${ }^{2}$ (Table-1), (Fig-1)

Table 1: Force exerted on the neck while forward flexion of head at varying degrees.

\begin{tabular}{|l|l|l|}
\hline Sr. no. & Angle of neck tilt & Force exerted on neck \\
\hline 1. & $0^{\circ}$ & $10-12$ pounds $(4.54-5.44 \mathrm{~kg})$ \\
\hline 2. & $15^{\circ}$ & 27 pounds $(12.25 \mathrm{~kg})$ \\
\hline 3. & $30^{\circ}$ & 40 pounds $(18.14 \mathrm{~kg})$ \\
\hline 4. & $45^{\circ}$ & 49 pounds $(22.23 \mathrm{~kg})$ \\
\hline 5. & $60^{\circ}$ & 60 pounds $(27.22 \mathrm{~kg})$ \\
\hline
\end{tabular}




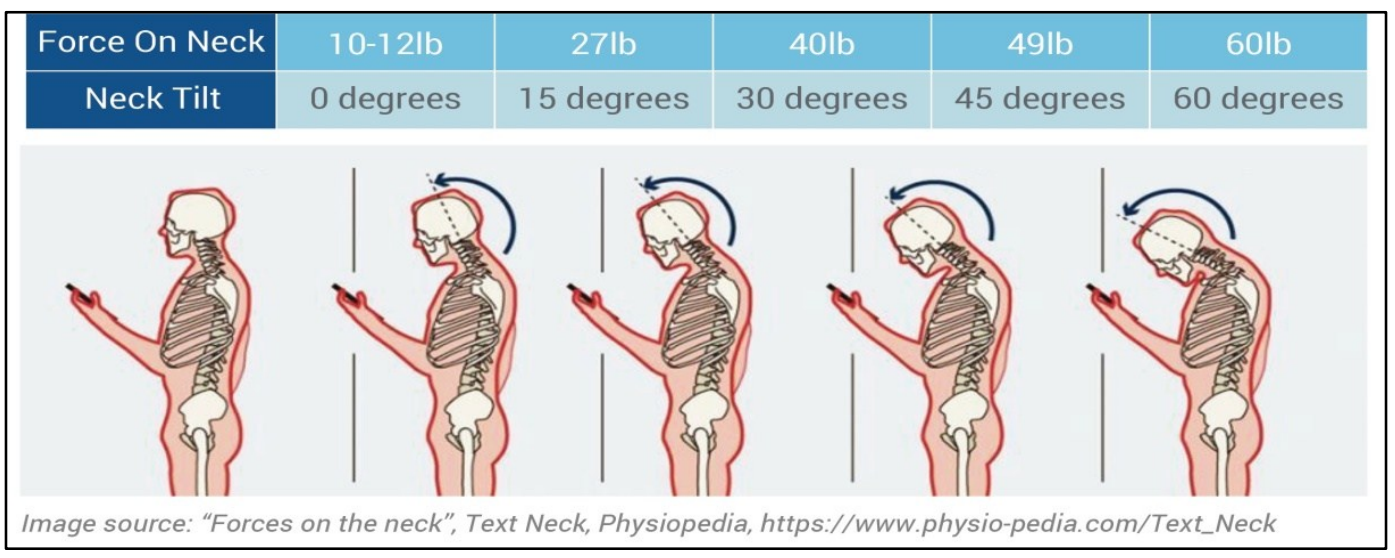

Fig-1: Force exerted on the neck while forward flexion of head at varying degrees.

This issue is a matter of concern for children because their heads are larger in respect of their body size than adults. So, they are at high risk of developing Text neck syndrome if they overuse mobile phones and other handheld devices. $^{2}$

- Common symptoms of Text neck syndrome ${ }^{5}-$

Text neck syndrome commonly shows one or more of the following symptoms -

(i) Pain in the neck, upper back, and/or shoulder This pain may be intense and stabbing or it may be a general achiness and soreness. It starts from one specific point of neck then it may radiate to upper back and shoulders.

(ii) Neck stiffness - Neck muscles can be strained by prolonged forward neck bending and produce neck stiffness.

(iii) Reduced mobility - Stiffness of neck leads to reduce mobility of neck.

(iv) Headache - Prolonged forward neck bending causes spasm of the muscles situated at the base of neck and become painful. This pain may radiate from the neck to the head and patient feels headache.

(v) Forward head posture and rounded shoulders Muscle present in the neck, chest and upper back can become deconditioned and imbalanced due to prolonged forward head posture. This deconditioning can make it difficult to maintain the normal posture of neck and shoulders. (vi) Numbness over the neck, upper back and shoulders due to continuous strain. There is also numbness and tingling of the upper extremities.

(vii) Muscular weakness - Shoulder muscles and especially trapezius, scalene muscles, rhomboids and sternocleidomastoid muscle are the main to go for weakness. $^{2}$

- Complication of Text neck syndrome - $^{-}$

If text neck is untreated then it may lead to some serious permanent damage which are given below -

(i) Flattening of the spinal curve

(ii) Onset of early arthritis

(iii) Spinal misalignment

(iv) Spinal degeneration

(v) Disc compression

(vi) Disc herniation

(vii) Nerve damage

(viii) Muscle damage

(ix) GI problem

(x) Loss of lung volume capacity

- Preventive measures for Text neck syndrome ${ }^{3,5}$

(i) Raise the mobile phone or other devices to eye level while texting or reading to avoid forward bending of neck.

(ii) Avoid excessive usage of handheld devices.

(iii) Take frequent breaks while using handheld devices.

(iv) Avoid prolonged static posture while using handheld devices. 
(v) Arch and stretch - Arch the neck and upper back backward periodically to ease muscle pain.

(vi) Exercise regularly - A strong, flexible back and neck are more able to handle extra stress. So, regular exercise is very beneficial here.

- Management of acute cases ${ }^{2,3}$ -

(i) Neck muscles warm up at regular interval - Warm up your neck muscle in every 30-40 mins of using handheld devices by sort of exercises like rotate your head, to and fro of head, change direction or posture etc. Repeat these exercises at least for 10 times.

(ii) Stretches - One can do different types of muscle stretch like side neck stretch, levator scapulae stretch, front neck stretch etc., hold this for 10-30 secs.

(iii) Chin tuck exercise - It is a type of neck exercise that can help to reduce neck pain from poor posture. Repeat this exercise for at least 10 times.

(iv) Apply ice and/or heat packs.

(v) Massage - It helps to reduce pain by reducing muscle tension and spasm.

(vi) Use analgesics - It helps to reduce pain but must be used with caution.

- Management of chronic cases ${ }^{2}$ -

(i) Physical therapy

(ii) Use analgesics but with caution

(iii) Cervical epidural steroid injections

(iv) Cervical facet injections

(v) Trigger point injections

It is difficult to correlate Text neck syndrome exactly with diseases mentioned in Ayurvedic texts. But it can be included under Vatavyadhi. By some extent it can be correlated with Manyastambha due to similarity in symptoms like pain and stiffness in the neck. Manyastambha is one among the eighty Vataja nanatmaja vyadhi. ${ }^{6}$ The term 'Manyastambha' is made up of two words 'manya' and 'stambha'. The word 'manya' means 'back or nape of the neck' and the word 'stambha' means ' stiffness or rigidity'. ${ }^{7}$ So, it can be said that Manyastambha is a disease in which the neck becomes stiff or rigid as a result there is impaired movements of neck. According to Acharya Caraka, injury to the head gives rise to Manyastambha. ${ }^{8}$ Acharya Vagbhata has mentioned it as a symptom of Antarayam. ${ }^{9}$ As per Acharya Sushruta - sleeping dur- ing day time, improper way of sitting, standing and gazing upwards or downwards for prolonged periods cause aggravation of vata. This aggravated vata gets avrita (enveloped or occluded) by kapha and produces Manyastambha. ${ }^{10}$ The Samprapti ghatakas of this disease are as follows. ${ }^{11}$

- Dosha: Vata pradhana kapha dosha

- Dushya: Dhatu - Mamsa, meda, asthi; Upadhatu Sira, snayu, kandara.

- Agni: Vishamagni

- Srotas: Mamsavaha, asthivaha

- Sroto dushti: Sanga, vimarga gamana

- Adhishthana: Manya

- Roga marga: Madhyama roga marga

- Svabhava: Ashukari/chirakari

Its common symptoms are stretching, stiffness and pain in the neck muscles ${ }^{12}$ along with restricted movements of neck.

Ayurvedic management of Text neck syndrome:

- Chikitsa sutra (Treatment principles) ${ }^{13-16}$

For the management of Text neck syndrome, treatment principles of Manyastambha can be followed. They are as follows -

(i) Nidana parivarjana (avoidance of etiological factors)

(ii) Abhyanga (massage with oil) by saindhavadi taila and vishagarbha taila etc.

(iii) Ruksha swedana (dry fomentation) like baluka sweda etc.

(iv) Nasya karma (nasal medication) like katphala nasya (by fine powder of katphala tvak) etc.

(v) As per Bhavamishra -

- The neck part involved is massaged with oil or ghrita. Then the area is covered with leaves of $\mathrm{Ar}$ $k a$ or Eranda and hot fomentation are repeatedly given.

- Kukkutanda drava (white part of hen's egg) is heated along with saindhava lavana and ghrita then applied over greeva pradesha and mardana should be done. This procedure relieves Manyastambha.

(vi) Greeva basti by saindhavadi taila and vishagarbha taila etc. 
(vii) If a disease is caused by the occlusion of vayu by kapha then the patient should be given barley and meat of animals as well as birds inhabiting arid zone as food. He should be given Tikshna sweda (strong fomentation), Niruha types of medicated enema, $\mathrm{Va}$ mana (emetic therapy) and Virechana (purgation ther- apy). Old ghrita, sesame oil and mustard oil are useful in this condition.

\section{- Shamana aushadhis -}

In this disease different types of shamana aushadhis can be used. They are mentioned in Table-2

Table 2: List of medicines. ${ }^{17,18}$

\begin{tabular}{|c|c|c|c|c|}
\hline Sr. no. & Dosage forms & Name of medicines & Dosage & Anupana \\
\hline 1. & Rasa/bhasma & $\begin{array}{l}\text { Vatagajankush rasa, Vatachintamani rasa, Go- } \\
\text { danti bhasma etc. }\end{array}$ & $\begin{array}{l}\text { 125-250 mg twice } \\
\text { daily }\end{array}$ & Lukewarm water \\
\hline 2. & Vati & Agnitundi vati, Vishtinduka vati etc. & $\begin{array}{l}\text { 125-250 mg twice } \\
\text { daily }\end{array}$ & Lukewarm water \\
\hline 3. & Guggulu & $\begin{array}{l}\text { Mahayogaraja guggulu, Trayadasanga guggulu, } \\
\text { Simhanada guggulu etc. }\end{array}$ & $\begin{array}{l}500 \mathrm{mg}-1 \mathrm{gm} \\
\text { twice daily }\end{array}$ & Lukewarm water \\
\hline 4. & Churna & $\begin{array}{l}\text { Shunthi churna, Panchakola churna, Ashwagan- } \\
\text { dha churna etc. }\end{array}$ & 3-6 gm twice daily & Lukewarm water \\
\hline 5. & Kwatha & $\begin{array}{l}\text { Panchamula kwatha, Dasamula kwatha, Maha- } \\
\text { rasnadi kwatha etc. }\end{array}$ & $\begin{array}{l}20-40 \mathrm{ml} \text { twice } \\
\text { daily }\end{array}$ & $\begin{array}{l}\text { With equal amount } \\
\text { of water }\end{array}$ \\
\hline 6. & Ashava/Arishta & Dasamularishta, Balarishta, Drakshasava etc. & $\begin{array}{l}15-30 \quad \mathrm{ml} \text { twice } \\
\text { daily }\end{array}$ & $\begin{array}{l}\text { With equal amount } \\
\text { of water }\end{array}$ \\
\hline
\end{tabular}

- Yoga-asana ${ }^{19}$

Text neck syndrome occurs as a result of poor posture of neck. In this disease there is excessive stress and strain over neck. Yoga-asana helps to relax the stressed muscles of the neck and relieves pain as well as other associated symptoms. Yoga-asanas which are beneficial in this disease, are as follows -

1. Bhujangasana (Cobra pose)
2. Ardha matsyendrasana (Half fish pose or sitting half spinal twist pose)

3. Ardha ushtrasana (Half camel pose)

4. Marjarasana (Cat pose)

- Patha-apathya (Do's and don'ts) -

Text neck syndrome can be included under Vatavyadhi. So, pathya-apathya of Vatavyadhi can be followed here. (Table-3)

Table 3: List of pathya-apathya. ${ }^{20}$

\section{Pathya ahara}

Godhuma (wheat), shali rice, kulattha (horse gram), masha (black gram), patola (pointed gourd), shigru (drumstick), vartaka (brinjal), lashuna (garlic), dadima (pomegranate), draksha (grapes), ghrita, jangala mamsa (meats of animal inhabiting arid land) etc.

\section{Apathya ahara}

Chanaka (chickpea), kalaya (pea), mudga (green gram), jambu (Indian blackberry), karavellaka (bitter gourd), kamala nala (lotus stem), udumbara (cluster fig), shushka mamsa (dried meat), kshaudra (honey) etc.

\section{Pathya vihara}

Abhyanga (oil massage), mardana (kneading or massage), basti (medicated enema), ruksha sweda (dry fomentation), samvahana, samshamana aushadha sevana etc.

\section{Apathya vihara}

Chinta (anxiety), prajagarana (night awakening), vega vidharana (suppression of natural urges), shrama (exertion), anasana (fasting) etc.

\section{DISCUSSION}

Text neck syndrome is a painful condition of neck associated with neck stiffness and restricted movements of neck. It is occurred by forward bending of neck while using handheld devices for prolonged period of time. In this article, both preventive and curative measures of this disease have been discussed in detail. One should follow all the preventive measures 
which are described above to avoid this disease. Above described Ayurvedic management can help to combat this disease by doing samprapti vighatana which is a prime objective of any treatment. At first patient should follow the Nidana parivarjana (avoidance of etiological factors), that means he must avoid prolonged use of handheld devices. Abhyanga and Swedana are very beneficial for this condition. They help to remove stiffness and reduce pain. It is an urdhwajatrugata roga. Hence, Nasya karma is very much important for its treatment. It helps to remove aggravated doshas and relieves symptoms of this disease. On the other hand, Shamana aushadhi causes pacification of aggravated doshas. If aggravated vayu and kapha are pacified, then automatically its symptoms are also reduced. Text neck syndrome occurs as a result of repetitive stress over the neck. So, proper practice of Yoga-asana helps to remove this stress over the neck and subsides the symptoms of this disease.

\section{CONCLUSION}

Text neck syndrome is gradually increasing day by day in our society. Our young generation is mostly affected from it because they are addicted to mobile phones and such other handheld devices. They spend their most of the times by hunching over the mobile phones. This affects their health badly. So, they must avoid the prolonged use of mobile phones. In this article Text neck syndrome along with its Ayurvedic management have been discussed in detail. Nidana parivarjana, Shodhana chikitsa, Shamana chikitsa and Yoga-asana have been included under the Ayurvedic management of this disease. These treatment principles help to cure this disease successfully if they are properly administered.

\section{REFERENCES}

1. https://www.statista.com/statistics/467163/forecast-ofsmartphone-users-in-india

2. Neupane S, Ali UTI, Mathew A. Text Neck Syndrome - Systematic Review. Imperial Journal of Interdisciplinary Research. 2017; 3(7): 141-148. Available from: https://www.onlinejournal.in

3. https://www.physio-pedia.com/Text_Neck.

4. https://www.text-neck.com
5. https://www.spine-health.com

6. Sharma RK, Dash B. Agnivesha's Caraka Samhita. Vol. I (Sutra sthana-20/11). Reprint ed. Varanasi: Chowkhamba Sanskrit Series Office; 2012. p. 363.

7. William M. A Sanskrit - English Dictionary. Reprint ed. Delhi: Motilal Banarsidass Publishers Private Limited; 1999. p. 789.

8. Sharma RK, Dash B. Agnivesha's Caraka Samhita. Vol. VI (Siddhi sthana-9/6). Reprint ed. Varanasi: Chowkhamba Sanskrit Series Office; 2012. p. 329.

9. Murthy KRS. Vagbhata's Ashtanga Hridayam. Vol. II (Nidana sthana-15/22). Reprint ed. Varanasi: Chowkhamba Krishnadas Academy; 2012. p. 152.

10. Murthy KRS. Illustrated Sushruta Samhita. Vol. I (Nidana Sthana-1/67). Reprint ed. Varanasi: Chaukhambha Orientalia; 2016. p. 471.

11. Bali Y. Neck Pain: An Ancient View. International Research Journal of Pharmacy. 2012; 3(4): 22. Available from - https://www.irjponline.com

12. Sharma AK. Kayachikitsa. Part III. Reprint ed. Delhi: Chaukhambha Orientalia; 2014. p. 61.

13. Murthy KRS. Illustrated Sushruta Samhita. Vol. II (Chikitsa Sthana-5/20). Reprint ed. Varanasi: Chaukhambha Orientalia; 2016. p. 71.

14. Tripathi I. Cakradatta of Shri Cakrapanidatta. (Chapter19, Verse-19). Reprint ed. Varanasi: Chaukhambha Sanskrit Bhawan; 2018. p. 134.

15. Sitaram B. Bhava Prakasha of Bhavamishra. Vol. II (Madhyam Khanda-24/76-78). Reprint ed. Varanasi: Chaukhambha Orientalia; 2014. p. 272.

16. Sharma RK, Dash B. Agnivesha's Caraka Samhita. Vol. V (Chikitsa sthana-28/187,188). Reprint ed. Varanasi: Chowkhamba Sanskrit Series Office; 2012. p. 6970 .

17. Sharma AK. Kayachikitsa. Part III. Reprint ed. Delhi: Chaukhambha Orientalia; 2014. p. 16-18.

18. Singh VK. Vata Vyadhi Cikitsa Vigyana. $1^{\text {st }}$ ed. New Delhi: Chaukhambha Publications; 2013. p. 79.

19. Asthana AK, Asthana M, Aggarwal D. Text neck and its Management. Int J Ayu Pharm hem. 2020; 12(1): 297. Available from - https://www.ijapc.com

20. Sharma AK. Kayachikitsa. Part III. Reprint ed. Delhi: Chaukhambha Orientalia; 2014. p. 20.

\section{Source of Support: Nil \\ Conflict of Interest: None Declared}

How to cite this URL: Md Tanzil Ansari \& Sukumar Ghosh: Concept Of Text Neck Syndrome And Its Management Through Ayurveda. International Ayurvedic Medical Journal \{online\} 2021 \{cited February, 2021\} Available from: http://www.iamj.in/posts/images/upload/447 452.pdf 